\title{
EFFECTS OF ALGICIDE (COPPER SULFATE) APPLICATION ON SHORT-TERM FLUCTUATIONS OF PHYTOPLANKTON IN LAKE PARANOÁ, CENTRAL BRAZIL
}

\author{
PADOVESI-FONSECA, C. and PHILOMENO, M. G. \\ Departamento de Ecologia/IB, Universidade de Brasília, UnB, Brazil \\ Correspondence to: Claudia Padovesi-Fonseca, Departamento de Ecologia/IB, UnB, ICC Ala Sul, \\ CEP 70910-900, Brasília, DF, Brazil, e-mail: padovesi@unb.br \\ Received November 13, 2002 - Accepted October 6, 2003 - Distributed November 30, 2004
}

(With 3 figures)

\begin{abstract}
Short-term fluctuations and structure of phytoplankton were examined for two months in the dry season (August-September/1997) in a eutrophic reservoir of central Brazil. Algicide treatment for the control of Microcystis aeruginosa bloom influenced the short-term variation pattern of the phytoplankton community. Algicide treatment was effective in controlling $M$. aeruginosa bloom, but it also influenced the Cylindrospermopsis raciborskii population. These species retained low densities, showing small colonies and trichomes, respectively. Drops in Cyanobacteria populations following algicide treatment were succeeded by progressive increase in Chlorophyta. The shifts in environmental conditions may have allowed the development of this group. In this study correspondence analysis of abundance data for phytoplankton assemblage in lake Paranoá revealed that available light, rather than chlorophyll-a, total suspended material, and water temperature, accounted for most of the short-term fluctuation in phytoplankton structure during algicide application. Canonical correspondance analysis (CCA) showed the primary importance of water transparency changes in abundance of taxa in the community. Algicide treatment for the control of nuisance blooms is discussed as a contribution to improved efficiency in reservoir management.
\end{abstract}

Key words: Cyanobacteria, Chlorophyta, reservoir, Brazil.

\section{RESUMO}

Efeitos da aplicação de algicida (sulfato de cobre) sobre flutuações de curta duração do fitoplâncton no lago Paranoá, Brasil central

Flutuações de curta duração e a estrutura do fitoplâncton foram analisadas ao longo de dois meses na estação seca (agosto-setembro de 1997) em reservatório eutrófico do Brasil central. A aplicação de algicida para o controle de florescimentos de Microcystis aeruginosa exerceu influência sobre a variação temporal da comunidade fitoplanctônica, sendo efetiva também no controle do florescimento de $M$. aeruginosa e sobre a população de Cylindrospermopsis raciborskii. Ambas permaneceram em baixas densidades numéricas, com pequenas colônias e tricomas, respectivamente. Quedas bruscas de populações de Cyanobacteria após o tratamento de algicida foram seguidas por progressivo aumento de Chlorophyta. Mudanças de condições ambientais podem ter permitido o desenvolvimento deste último grupo. Análise de correspondência de dados de abundância do fitoplâncton no lago Paranoá revelou que a variável luz disponível se relacionou mais à flutuação de curta duração em estrutura do fitoplâncton do que a clorofila-a, o material suspenso total e a temperatura da água. A ACC constatou que as mudanças de transparência de água foram de primordial importância na abundância dos taxa fitoplanctônicos. O tratamento de algicida no controle de florescimentos algais é discutido aqui em relação ao gerenciamento eficiente de reservatórios.

Palavras-chave: Cyanobacteria, Chlorophyta, reservatório, Brasil. 


\section{INTRODUCTION}

Lake Paranoá is a reservoir located in the urban area of Brasília, the capital of Brazil. Constructed in 1959 to generate hydroelectric power, it was also designed to provide recreational facilities and to improve regional climatic conditions. The reservoir rapidly became eutrophic, with the occurrence of large blooms of Microcystis aeruginosa, extended areas of aquatic macrophytes (Eichhornia crassipes), and frequent fish kills (Altafin et al., 1995 and references).

This progressive eutrophication has been related to high inorganic nutrient input mainly deriving from sewage effluent (Felizatto et al., 2000). Several factors have contributed to water quality deterioration, including the rapid growth of Brasília within the lake catchment area and the installation of two sewage plants having inadequate treatment processes.

The rapid urban development of Brasília initially concentrated the population in the southern area, the excess nutrient inputs from which resulted in frequent and severe blooms of M. aeruginosa in the southern part of the reservoir (the Riacho Fundo branch). The Water and Sewage Treatment Company of Brasília (CAESB) has controlled these blooms by applying copper sulfate as an algicide.

Changes in phytoplankton community structure, and particularly the occurrence of certain species, can directly affect water quality and interfere in urban utilization of the reservoir.

This present work aimed to analyze the temporal phytoplankton fluctuation in two months of the dry season (August-September 1997), at a point situated in the Riacho Fundo branch, by investigating the influence of copper sulfate application on the phytoplankton community structure.

\section{MATERIAL AND METHODS}

Lake Paranoá $\left(15^{\circ} 48^{\prime} \mathrm{S}, 47^{\circ} 47^{\prime} \mathrm{W}\right)$ is a eutrophic reservoir (area $38.1 \mathrm{~km}^{2}$, volume $498.6 \times 10^{6} \mathrm{~m}^{3}$, max. depth $40 \mathrm{~m}$, mean depth $13 \mathrm{~m}$ ) situated in the urban region of Brasília, at an altitude of $1,000 \mathrm{~m}$. The regional climate is characterized by two seasons: the cool-dry (May-September) and the warm-rainy (October-April). Four main tributaries feed the reservoir: Ribeirão do Torto and Córrego do Bananal (northern part), and Ribeirão do Gama and Riacho Fundo (southern part). Lake Paranoá has an irregular form, with a central area and four extended branches, corresponding to former valleys of the tributaries (Fig. 1). The Riacho Fundo branch is the more eutrophic part of the reservoir because it receives the effluents from the sewage treatment plant in the southern part of Brasília as well as the loads transported from the Riacho Fundo tributary. This branch has a $4.6 \mathrm{~km}^{2}$ area, $39.3 \times 10^{6} \mathrm{~m}^{3}$ volume, $19 \mathrm{~m}$ maximum depth, and $8.6 \mathrm{~m}$ mean depth (Mattos et al., 1992).

This study was carried out at a fixed sample station located in the Riacho Fundo branch of the reservoir. Phytoplankton samples were collected at intervals of 2-3 days during two months of the dry season (August-September 1997).

The added amounts of copper sulfate $(\mathrm{kg})$ were provided by the Water and Sewage Treatment Company of Brasília (CAESB). Algicide treatment was applied in the Riacho Fundo branch. Methods used for limnological variables are described in Padovesi-Fonseca et al. (2002).

The samples were taken from $1 \mathrm{~m}$ to the surface using a Van Dorn bottle and then poured together to form composite samples. They were preserved in $4 \%$ formalin. Studies of the primary production in many parts of Paranoá reservoir (Pinto-Coelho \& Giani, 1984) considered $1 \mathrm{~m}$ the most productive depth of the euphotic layer.

Qualitative analysis was made using a concentrated live sample. Quantitative examination was performed by inverted microscopy (Wetzel \& Likens, 1991). For Cylindrospermopsis raciborskii, a dominant species, 30 fields were counted, along with 60 fields for the other algae. The units for the phytoplankton counts were cells, trichomes, and colonies.

The relationships between species and environmental data were examined by canonical correspondence analysis (CCA) using PC-ORD (Version 3.17). As described in ter Braak (1994), the CCA is a direct gradient analysis technique in which the unimodal species response to environmental variables is incorporated. Linear environmental-variable combinations are selected to bring about maximum separation in species distributions. The CCA procedure produces an ordination diagram in which species (or samples) are represented by points and environmental variables by vectors. The longer the vector, the greater the correlation between the variable and the ordination axes, and the greater the influence of that variable on the community variation pattern (ter Braak, $o p$. cit.) Because environmental vectors also extend in the direction opposite (negative) the origin, a negative 
relationship between a group and an environmental variable can also be indicated. The significance of the analysis relating environmental variables to phytoplankton taxa was tested by conducting Monte Carlo permutations on the group-environment relationship (ter Braak, op. cit.).

Phytoplankton taxa abundance data were logtransformed before CCA to dampen the effects of dominant taxa (Palmer, 1993).

\section{RESULTS}

The amounts of copper sulfate $(\mathrm{kg})$ applied in the Riacho Fundo branch were 1,000 kg (5 Aug. 1997), $700 \mathrm{~kg}$ (8 Sept. 1997), and $300 \mathrm{~kg}$ (16 Sept. 1997).

In this study, about 37 taxa, most of them Chlorophyta (at least 26 taxa), were identified within the phytoplankton community. Despite many taxa of green algae, Cyanobacteria predominated quantitatively, due to high relative abundance (>90\%) of Cylindrospermopsis raciborskii.

During this study, algicide treatment was applied in the afternoon, with the copper sulfate proving effective in lysing cyanobacterial cells. Consequently, drops of Microcystis aeruginosa and Cylindrospermospsis raciborskii densities were observed, and these species retained small fragments of colonies and trichomes, respectively, for almost three weeks.

Microcystis aeruginosa showed a peak of abundance in early August, with 53,500 colonies $\mathrm{L}^{-1}$ (Fig. 2a). Population size then declined abruptly and remained low during three consecutive weeks. During this period, the lowest density was of 500 colonies $\mathrm{L}^{-1}$ (9 Aug.), with this species disappearing entirely in mid-August. But by the end of the month, the species reappeared although in smaller colonies. Another peak occurred in early September, combined with an increase of colony sizes, followed by a density decrease in September.

Cylindrospermopsis raciborskii had a similar pattern of temporal variation (Fig. 2b). During the sampling period, this species fluctuated widely, and showed three peaks of abundance. The first peak occurred in early August, reaching 711,300 trichomes $\mathrm{L}^{-1}$, followed by an abrupt decline in population size, and remained low for three weeks. During this time, the lowest density was 6,200 trichomes $\mathrm{L}^{-1}$ in midAugust, with the trichomes having already broken into small fragments. The following two peaks occurred in consecutive weeks, reaching 451,000 trichomes $\mathrm{L}^{-1}$ in early September. Heterocyts were absent in trichomes of this species.

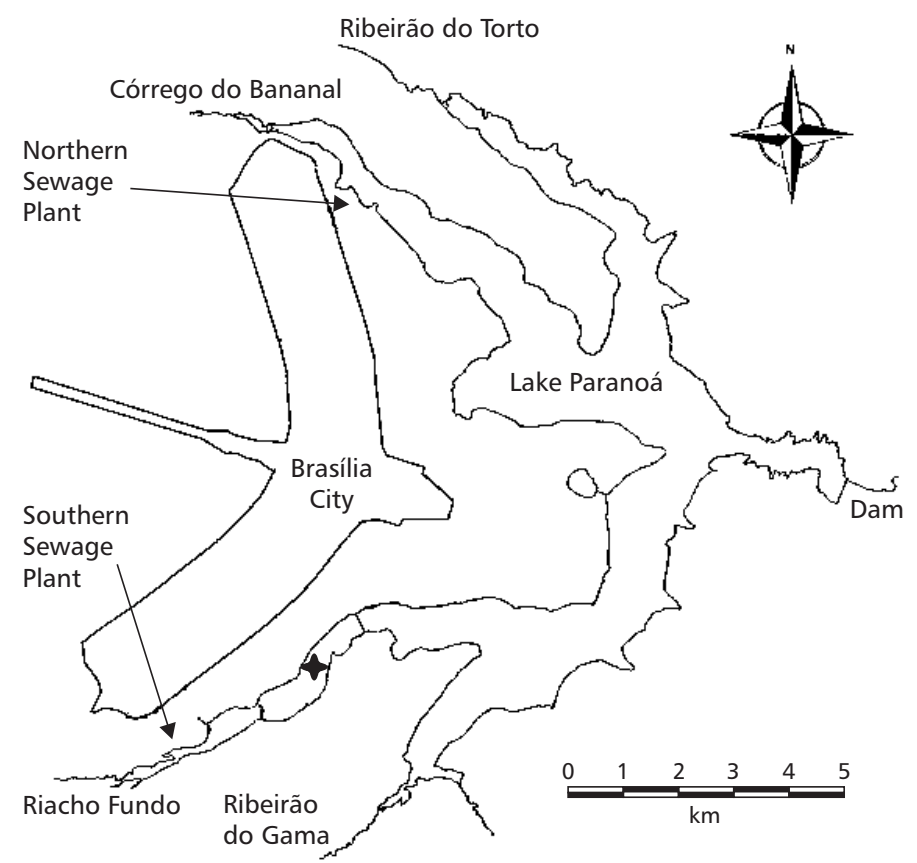

Fig. 1 - Location of sampling point in lake Paraná. 
During August Chlorophyta fluctuated widely, with consecutive peaks of abundance, reaching 35,300 org L $\mathrm{L}^{-1}$ in late August (Fig. 2c). This progressive density increase occurred simultaneously with a pronounced decrease in cyanobacterial abundance. In September, the Chlorophyta showed a temporal fluctuation similar to that of $C$. raciborskii.

In CCA, the eigenvalues for the first two canonical axes were 0.094 and 0.013 , respectively. Together these amounted to $68.7 \%$ of the variance in the phytoplankton data (Table 1). The first canonical axis accounted for $60.3 \%$ of the explained variance. This axis was significantly related to species composition (Monte Carlo permutation test, $\mathrm{p}=0.015$ ), indicating a strong relationship between phytoplankton taxa and the environmental variable Secchi transparency. The second canonical axis accounted for $8.4 \%$ of the explained variance. Axis 2 expressed variation in chlorophyll-a, total suspended material, and water temperature on phytoplankton taxa (Monte Carlo permutation test, $\mathrm{p}>0.05$ ).

Phytoplankton taxa are situated far from the origin on both ordination axes (Fig. 3). Most taxa encompassing the division Chlorophyta increased in density as Secchi transparency increased; all of them had negative scores on axis 1 . In contrast, Microcystis aeruginosa and Cylindrospermopsis raciborskii increased in density at low Secchi transparency and had positive scores on axis 1 .

\section{DISCUSSION}

Copper sulfate application to control Microcystis aeruginosa blooms has been done by CAESB in lake Paranoá, especially in the Riacho Fundo branch. The amount applied in lake Paranoá during 1997 exceeded 3,000 kg (CAESB data).

In this study, the treatment was effective on Microcystis aeruginosa colonies and it also influenced the Cylindrospermopsis raciborskii population. These algae populations retained low densities and fragments of colonies/trichomes for nearly three weeks. In this way, the algicide application caused cell lysis and sinking and, according to Jones \& Orr (1994), this algicide treatment has been effective in lysing cyanobacterial cells.

TABLE 1

Summary of the relationship of environmental variables to CCA axes.

\begin{tabular}{|c|c|c|}
\hline & \multicolumn{2}{|c|}{ Axes } \\
\hline & 1 & 2 \\
\hline Eigenvalues & 0.094 & 0.013 \\
\hline Phytoplankton-environmental correlations & 0.905 & 0.856 \\
\hline Percentage variance of phytoplankton taxa & 60.3 & 8.4 \\
\hline \multicolumn{3}{|l|}{$\begin{array}{l}\text { Intra-set correlations with environmental } \\
\text { variables: }\end{array}$} \\
\hline Electric conductivity $\left(\mu \mathrm{S} \mathrm{cm}^{-1}\right)$ & 0.166 & -0.079 \\
\hline Dissolved oxygen (\% saturation) & 0.176 & -0.021 \\
\hline $\mathrm{pH}$ & 0.405 & -0182 \\
\hline Water transparency (Secchi disc) $(\mathrm{cm})$ & -0.773 & 0.191 \\
\hline Chlorophyll-a $\left(\mu \mathrm{g} \mathrm{L}^{-1}\right)$ & $\underline{0.543}$ & $\underline{0.747}$ \\
\hline Temperature $\left({ }^{\circ} \mathrm{C}\right)$ & 0.216 & -0.775 \\
\hline Suspended material $\left(\mathrm{mg} \mathrm{L}^{-1}\right)$ & 0.336 & -0.570 \\
\hline
\end{tabular}

Underlined values are for those variables with the strongest positive and negative correlations with the respective axis. 

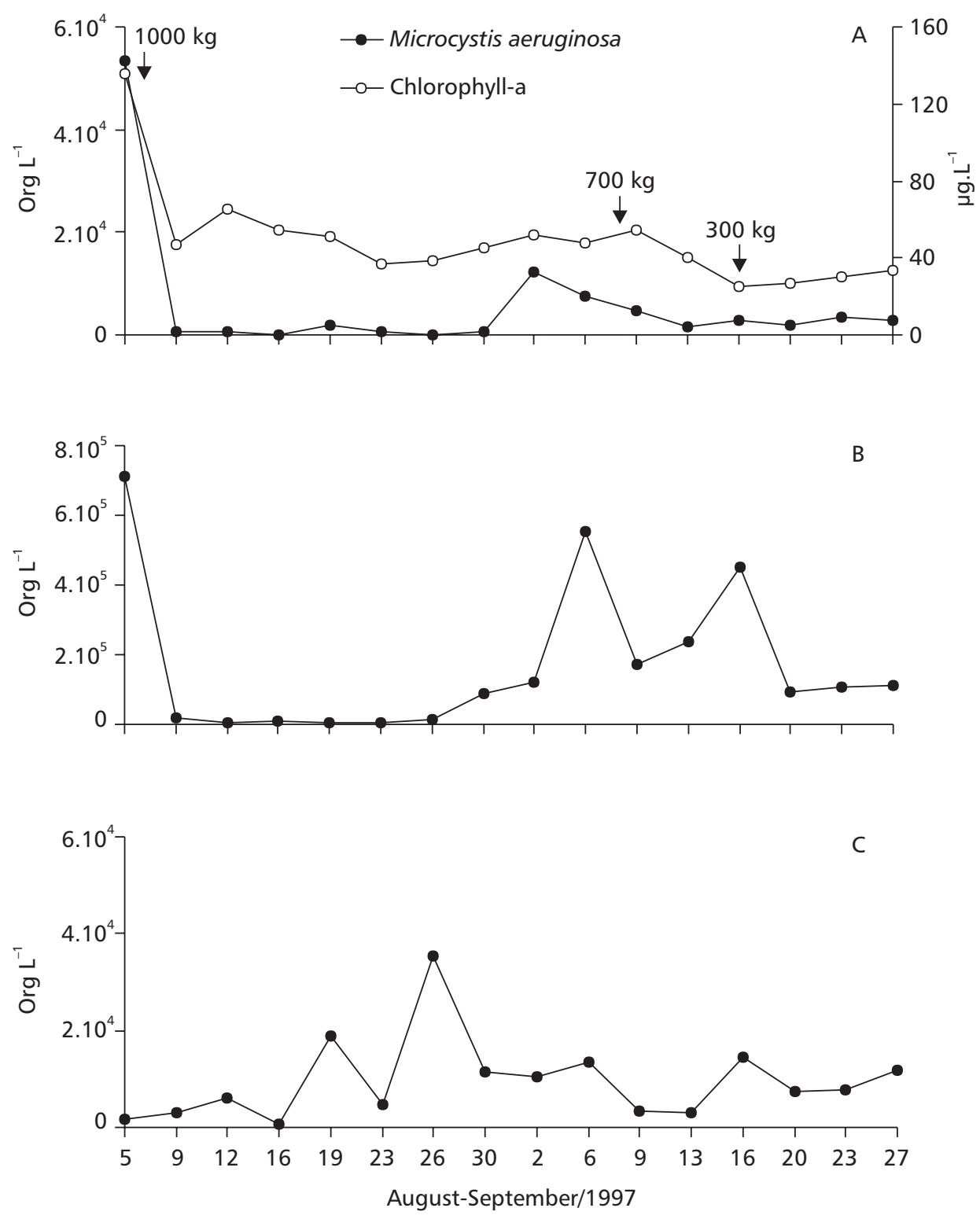

Fig. 2 - Temporal fluctuation in density of the Cyanobacteria Microcystis aeruginosa and Cylindrospermopsis raciborskii, Chlorophyta, and chlorophyll-a during August-September 1997 in lake Paranoá (Brazil). A) Microcystis aeruginosa and chlorophyll-a, showing algicide additions, B) Cylindrospermopsis raciborskii and C) Chlorophyta.

The phytoplankton of lake Paranoá has been dominated by Cylindrospermopsis raciborskii (Cyanobacteria) for at least twenty years (Palmer, 1969; Branco \& Senna, 1996 and references). According to Lewis (1986), in lakes in which, generally under eutrophic conditions, phytoplankton assemblages are dominated by one taxon, temporal changes in phytoplankton are highly influenced by allogenic factors. The effects of high nutrient levels in this lake were evidenced by absence of heterocyts in $C$. raciborskii trichomes.

Algicide treatment may be considered an allogenic disturbance in temporal fluctuations of phytoplankton in lake Paranoá. 


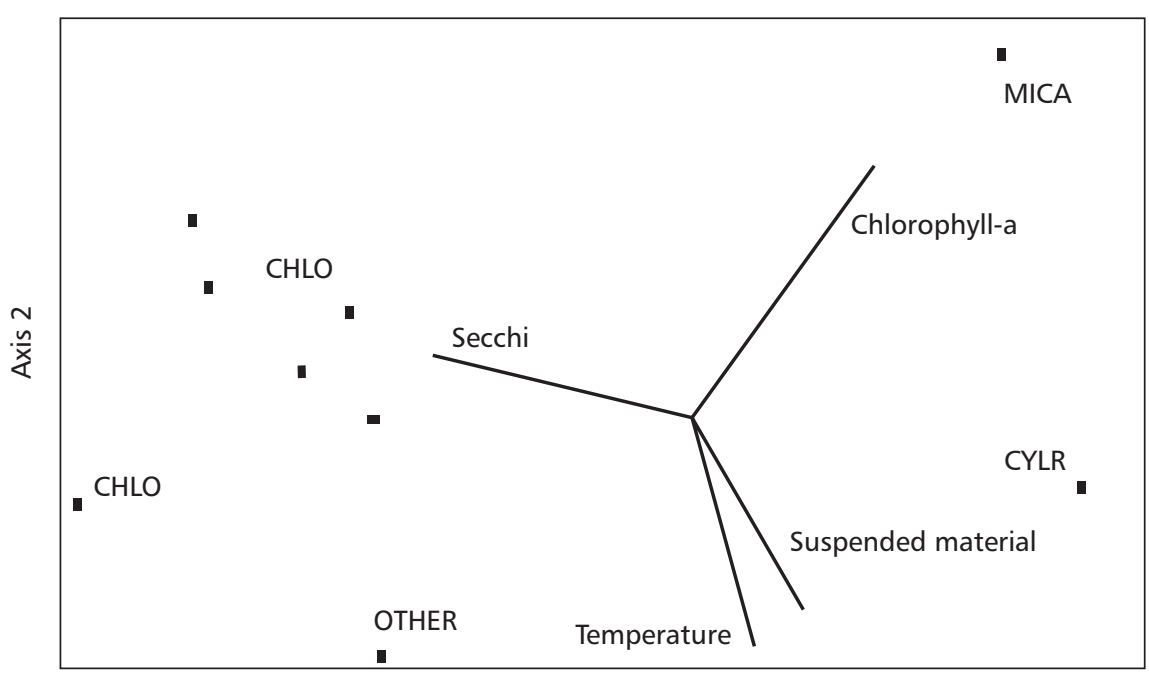

Axis 1

Fig. 3 - Biplot for phytoplankton taxa and environmental variables based on canonical correspondence analysis (CCA). Environmental variables are represented by lines and phytoplankton taxa are represented by crosses and identified as: MICA, Microcystis aeruginosa; CYLR, Cylindrospermopsis raciborskii; CHLO, Chlorophyta; OTHER, other phytoplankton taxa. The lines indicate significant $(\mathrm{p}<0.05)$ and independent environmental variables.

The algicide application caused abrupt phytoplankton changes in followed by environmental condition changes (see results). This disruption was severe but with irregular frequency during a short time period. Regularity and extension of allogenic factors are important because they allows estimating community structure impact. According to Reynolds (1997), a community is able to regulate its structure depending on the disturbance level resulting from external forces.

Cyanobacteria dominance has been documented in the case of eutrophic aquatic systems, along with the existence of unpalatable and toxic species. These properties prevent grazing by zooplankton (Webster $\&$ Peters, 1978), and interfere in the development of other algae (Kearns \& Hunter, 2000). Both species, Cylindrospermopsis raciborskii and Microcystis aeruginosa, can produce toxins (Starkweather \& Kellar, 1987). Experimental studies revealed virtual absence of grazing on C. raciborskii in lake Paranoá (Starling, 1993). Also, cyanobacterial blooms can produce extremely potent toxins that are able to kill a vast variety of organisms, including fishes and humans (Lagos et al., 1999; Matthiensen et al., 2000). Toxic cyanobacterial blooms have been frequent events in Brazil, especially in drinking-water reservoirs. In the city of Caruaru in northeastern Brazil, 110 patients developed intoxication symptoms (with
70 deaths) related to hepatotoxins after routine hemodialysis treatment (Lagos et al., op. cit. and references). These authors demonstrated the presence of toxins during Cylindrospermopsis raciborskii blooms in two Brazilian reservoirs. In lake Paranoá, analysis carried out by Sandra Azevedo (pers. comm.) identified toxins in Microcystis aeruginosa cells.

Phytoplankton blooms are often predictable features in eutrophic systems. Multiple interacting factors (physical, chemical, and biotic) lead to the development and persistence of algal blooms. Hydrological changes such as thermal stratification, water column turnover, and light conditions favor biomass growth and proliferation (Paerl, 1988). In lake Paranoá, Microcystis aeruginosa blooms have been more frequent and displaying greater magnitude at the end of the dry season, influenced by thermal stratification and the higher level of eutrophic conditions, as verified by Branco \& Senna (1994).

Loth et al. (1995) investigated the effects of artificial mixing on phytoplankton biomass and composition in large pelagic enclosures installed in a hypertrophic reservoir. This investigation demonstrated that the magnitude of chlorophyll peaks observed in the reservoir were depressed in the mixed enclosures, and the development of filamentous cyanobacteria was influenced by outcompetition with 
chlorophytes and diatoms. A simulation study done by Kuwata \& Miyazaki (2000) showed that the predominance of Microcystis at lower dilution rates of nitrogen and ammonium concentration influenced its final biomass. These results explain in part the occurrence of Microcystis blooms in nutrient-rich and slow-flowing waters.

In the Riacho Fundo branch, Microcystis aeruginosa blooms have been frequent, occurring as a massive accumulation of algae cells and accounting for a high portion of resident phytoplankton biomass. If a high external load of nutrients happens, surface blooms can rapidly be transformed into undesirable decomposing mats. Decreases in OD observed in this period seem to be related to algicide application, after which a high portion of dead algae sink. The decomposition process causes a decreasing oxygen concentration, particularly in bottom layers, as observed by Padovesi-Fonseca et al. (2002) during this sampling period. According to Hergenrader (1980), decreasing OD can cause intense fish kills.

During the dry season (April to September), the Paranoá reservoir tends to have a lower water level and reduced dam outflow, resulting in a higher residence time. As a consequence of the eutrophication process during this period, two fish kills occurred in the Riacho Fundo branch in June and July 1997, reaching $300 \mathrm{t}$ of dead fish (according to CAESB and the local fire chief). Applications of copper sulfate as algicide for the control of Microcystis aeruginosa blooms also took place from June to September 1997.

During this study, some limnological variables showed abrupt changes, and instability triggered irregular temporal fluctuations of limnological features (Padovesi-Fonseca et al., 2002). In general, algicide application seems to have had an important impact generally on the physical, chemical, and biological features of the reservoir.

The subsequent decreases in Cylindrospermopsis raciborskii and Microcystis aeruginosa populations following algicide application may have influenced the progressive chlorophyte density increases. During the algicide treatment in the dry period, abrupt changes were shown by some limnological variables: water transparency (from 0.5 to $1.10 \mathrm{~m}$ ), $\mathrm{pH}$ (from 8.0 to 6.5), oxygen content (from 10 to $6 \mathrm{mg} \mathrm{L}^{-1}$ ), and chlorophyll-a content (from 135.4 to $47.0 \mu \mathrm{g} \mathrm{L}^{-1}$ ). These shifts in environmental conditions may have allowed green algae development. According to Shapiro (1973), higher nutrient concentrations, lower $\mathrm{pH}$ and $\mathrm{CO}_{2}$ availability, and higher alkalinity can explain increased chlorophyte densities after a cyanobacterial decrease. In limnocorrals, Schrader et al. (2000) verified the death of nearly all phytoplankton with the addition of copper algicide. Green algae and diatoms rapidly recolonized the treated limnocorrals.

Correspondence analysis abundance data for phytoplankton assemblage in lake Paranoá during the dry period (August-September 1997) revealed that during algicide application available light accounted for more short-term fluctuation in phytoplankton structure than did chlorophyll-a, total suspended material, and water temperature. The CCA confirmed the primary importance of water transparency changes in abundance of taxa in the community during this study.

Short-term studies of algicides and other quality manipulations have been evaluated in enclosures (Schrader et al., 2000). The impact of algicide application for the control of cyanobacterial blooms in reservoirs, especially those situated in urban regions, can directly affect water quality and interfere in the reservoir utilization by city's population. The results obtained through this study are relevant in evaluating impacts caused by algicide application for controlling cyanobacterial blooms in reservoirs.

Algicide treatment to control Microcystis aeruginosa blooms was an emergency measure, but algicide amounts used, as well as the area in which they are applied, must be controlled for the efficient lake management. Sibley et al. (1994) demonstrated abrupt $\mathrm{pH}$ falls as a consequence of higher concentrations in copper sulfate treatments due to the toxicity of copper, which is especially relevant in situations where populations of M. aeruginosa and Cylindrospermopsis raciborskii are releasing toxins into the water. Cyanobacterial toxins are very stable chemically and may persist and result degradation depending on local environmental conditions (Jones \& Orr, 1994).

As investigated by De Souza et al. (1998) in a Brazilian eutrophic reservoir, the toxicity of these algal blooms can result in fish kills. Furthermore, they constitute threats to human health. But the treatment required to eliminate them must be carefully calculated.

\footnotetext{
Acknowledgements - This study is a result of the research program on eutrophication in lake Paranoá carried on by NEL (Group of Limnological Studies). The authors thank FINATEC and the Brazilian National Research Council (CNPq) for financial support (CNPq proc: 420010/97-1) and a grant to M. G. Philomeno (Graduate Scholarships). We are grateful to Luciana de MendonçaGalvão and Diogo L. P. Rocha for technical assistance during field work and laboratory analyses; Luciana de Mendonça-Galvão and Dayani F. Pereira for assistance in statistical analysis; the
} 
Fire Department of Brasília for use of field facilities and the Water and Sewage Treatment Company of Brasília (CAESB) for providing the copper sulfate $(\mathrm{kg})$ data.

\section{REFERENCES}

ALTAFIN, I. G., MATTOS, S. M., CAVALCANTI, C. G. B. \& ESTUQUI, V. R., 1995, Paranoá lake - limnology and recovery program, pp. 325-349. In: J. G. Tundisi, C. E. M. Bicudo \& T. Matsumura-Tundisi (eds.), Limnology in Brazil. BAS/SBL, Rio de Janeiro, 384p.

BRANCO, C. W. C. \& SENNA, A. C., 1994, Factors influencing the development of Cylindrospermopsis raciborskii and Microcystis aeruginosa in the Paranoá reservoir, Brasília, Brazil. Algolog. Stud., 75: 85-96.

BRANCO, C. W. C. \& SENNA, A. C., 1996, Phytoplankton composition, community structure and seasonal changes in a tropical reservoir (Paranoá reservoir, Brazil). Algolog. Stud., 81: 69-84.

De SOUZA, R. C. R., CARVALHO, M. C. \& TRUZZI, A. C., 1998, Cylindrospermopsis raciborskii (Wolosz.) Seenaya and Subba Raju (Cyanophyceae) dominance and a contribution to the knowledge of Rio Pequeno arm, Billings reservoir, Brazil. Environ. Toxicol. Water Qual., 13: 73-81.

FELIZATTO, M. R., ITONAGA, L. C. H., PINTO, M. A. T. \& CAVALCANTI, C. G. B., 2000, Statistical tendency analysis of lake Paranoá limnological data (1992-1999) and its trophic state classification based CEPIS methodology. International Symposium on Sanitary and Environmental Engineering (SIDISA 2000), book 2: 33-40.

HERGENRADER, G. L., 1980, Eutrophication of the Salt Valley reservoirs, 1968-73. I. The effects of eutrophication on standing crop and composition of zooplankton. Hydrobiologia, 71: 61-82.

JONES, G. J. \& ORR, P. T., 1994, Release and degradation of microcystin following algicide treatment of a Microcystis aeruginosa bloom in a recreational lake, as determined by HPLC and protein phosphatase inhibition assay. Wat. Res., 28: 871-876.

KEARNS, K. D. \& HUNTER, M. D., 2000, Green algal extracellular products regulate antialgal production in a cyanobacterium. Environ. Microbiol., 2(3): 291-297.

KUWAKA, A. \& MIYAZAKI, T., 2000, Effects of ammonium supply rates on competition between Microcystis novacekii (Cyanobacteria) and Scenedesmus quadricauda (Chlorophyta): simulation study. Ecol. Modelling, 135: 81-87.

LAGOS, N., ONODERA, H., ZAGATTO, P. A., ANDRINOLO, D., AZEVEDO, S. M. F. Q. \& OSHIMA, Y., 1999, The first evidence of paralytic shellfish toxins in the freshwater cyanobacterium Cylindrospermopsis raciborskii, isolated from Brazil. Toxicon, 37: 1359-1373.

LEWIS Jr., W. M., 1986, Phytoplankton succession in lake Valencia, Venezuela. Hydrobiologia, 138: 189-203.

LOTH, P., HERSCHEL, A., SCHROTER, K. \& LIEBERT, H. P., 1995, Algal blooms and duckweed covers in the Bleiloch reservoir (Thuringia) - Actual situation, casual analysis and first results of its overcome. Int. Revue Ges. Hydrobiol., 80: 535-561.
MATTHIENSEN, A., BEATTIE, K. A., YUNES, J. S., KAYA, K. \& CODD, G. A., 2000, [D-Leu(1)] microcystin-LR, from the cyanobacterium Microcystis RST 9501 and from a Microcystis bloom in the Patos lagoon estuary, Brazil. Phytochemistry, 55: 383-387.

MATTOS, S. P., ALTAFIN, I. G., FREITAS, H. J., CAVALCANTI, C. G. B. \& ALVES, V. R. E., 1992, Lake Paranoá, Brasília, Brazil: Integrated management plan for its restoration. Water Poll. Res. J. Canada, 27: 271-286.

PADOVESI-FONSECA, C., MENDONÇA-GALVÃO, L., PHILOMENO, M. G. \& PEREIRA, D. F., 2002, Temporal variation of physical and chemical properties in a eutrophic reservoir of central Brazil: lake Paranoá, Riacho Fundo branch (1997-98). (Submitted to Hydrobiologia.)

PAERL, H. W., 1988, Nuisance phytoplankton blooms in coastal, estuarine, and inland waters. Limnol. Oceanogr., 33: 823-847.

PALMER, C. M., 1969, A composite rating of algae tolerating organic pollution. J. Phycol., 5: 78-82.

PALMER, M. W., 1993, Putting things in even better order: the advantages of canonical correspondence analysis. Ecology, 74: 2215-2230.

PINTO-COELHO, R. \& GIANI, A., 1984, Variações sazonais do fitoplâncton e fatores físico-químicos no reservatório do Paranoá, Brasília. Cien. Cult., 37: 2000-2006.

REYNOLDS, C. S., 1997, Vegetation processes in the pelagic: a model for ecosystem theory. In: O. Kinne (ed.), Excellence in ecology, 9. Ecology Institute, Germany, 371p.

SCHRADER, K. K., TUCKER, C. S., DE REGT, M. Q. \& KINGSBURY, S. K., 2000, Evaluation of limnocorrals for studying the effects of phytotoxic compounds on plankton and water chemistry in aquaculture ponds. J. World Aquacult. Soc., 31: 403-415.

SHAPIRO, J., 1973, Blue-green algae: why they become dominant. Science, 179: 382-384.

SIBLEY, T. H., SHOTT, G. \& CHANG, C., 1994, Distribution and toxicity of copper in freshwater microcosms. Verh. Int. Verein. Limnol., 25: 2008-2012.

STARKWEATHER, P. L. \& KELLAR, P. E., 1987, Combined influences of particulate and dissolved factors in the toxicity of Microcystis aeruginosa (NRS-SS-17) to the rotifer Brahionus calyciflorus. Hydrobiologia, 147: 375-378.

STARLING, F. L. R. M., 1993, Análise experimental dos efeitos da tilápia-do-congo (Tilapia rendalli) e carpa-prateada (Hypophthalmichthys molitrix) sobre a estrutura da comunidade planctônica do lago Paranoá, Brasília (DF). Acta Limnol. Brasil., 4: 144-156.

ter BRAAK, C. J. F., 1994, Canonical community ordination. Part I. Basic theory and linear methods. Ecoscience, 1: 127-140.

WEBSTER, K. E. \& PETERS, R. H., 1978, Some size-dependent inhibitions of larger cladoceran filters in filamentous suspensions. Limnol. Oceanogr., 23: 1238-1245.

WETZEL, R. G. \& LIKENS, G. E., 1991, Limnological analyses. Springer-Verlag, NY, 429p. 